\title{
Renata Kwiatkowska
}

Uniwersytet Marii Curie-Skłodowskiej w Lublinie

e-mail: renata.kwiatkowska@umcs.lublin.pl

\section{WPLYW ZARZĄDZANIA WIERZYTELNOŚCIAMI NA KOSZTY W SPRAWOZDANIU FINANSOWYM}

\section{THE IMPACT OF DEBT MANAGEMENT ON COSTS IN THE FINANCIAL STATEMENTS}

DOI: $10.15611 /$ pn.2018.524.09

JEL Classification: D23, G32, M40

Streszczenie: Głównym celem opracowania jest analiza wpływu zarządzania wierzytelnościami na koszty w sprawozdaniu finansowym. Realizacja celu wymagała wyodrębnienia głównych obszarów zarządzania wierzytelnościami, wskazania kierunków oddziaływania zarządzania wierzytelnościami na koszty prezentowane i nieprezentowane w sprawozdaniu finansowym, dokonania pomiaru kosztów zarządzania wierzytelnościami na podstawie danych prezentowanych w sprawozdaniach finansowych wybranych jednostek z sektora przetwórstwa przemysłowego oraz porównania badanych jednostek w zakresie podejścia i kosztochłonności zarządzania wierzytelnościami. Proces poznawczy wymagał dokonania przeglądu literatury przedmiotu i sprawozdań finansowych badanych jednostek za 2017 r. oraz wykorzystania metody analizy i konstrukcji logicznej. Przeprowadzone badania ujawnity istnienie związku pomiędzy przyjętymi założeniami i kosztochłonnością zarządzania wierzytelnościami w badanych jednostkach.

Słowa kluczowe: zarządzanie wierzytelnościami, kosztochłonność, odpisy aktualizujące należności.

Summary: The main objective of the study is to analyse the impact of debt management on costs in the financial statements. This required the separation of the main areas of debt management, the indication of the impact of debt management on the costs presented and not presented in the financial statements, the measurement of debt management costs based on the financial statements of selected entities from the processing industry sector and comparison of the surveyed entities with regard to the approach and cost-management of debt management. The cognitive process required the review of the subject literature and financial reports of the surveyed entities for 2017, as well as the use of the analysis and logical construction method. The conducted research revealed the existence of a connection between the assumptions and the cost absorption of debt management of the surveyed entities.

Keywords: debt management, cost absorption, allowances for revaluation of receivables. 


\section{Wstęp}

Sprzedaż z odroczonym terminem płatności jest nieodzownym $i$ istotnym elementem praktyki gospodarczej. Według aktualnych danych [Główny Urząd Statystyczny 2018] udział wierzytelności (należności) w aktywach obrotowych przedsiębiorstw w Polsce wynosi 43,6 \% ${ }^{1}$. Wysoki poziom wskaźnika potwierdza znaczenie zarządzania wierzytelnościami dla bezpieczeństwa finansowego i rentowności podmiotów oraz uzasadnia rozpoznanie szczegółowych zagadnień w tym obszarze. Jednym z takich zagadnień jest wpływ zarządzania wierzytelnościami na poziom kosztów wykazywanych w sprawozdaniu finansowym. Perspektywę dla podejmowanych analiz stanowi teoria kosztów transakcyjnych wprowadzona przez R. Coase'a. Koszty zarządzania wierzytelnościami są składową kosztów transakcyjnych, które obejmują w szczególności koszty poszukiwania informacji, koszty zarządzania i zawierania kontraktów oraz koszty egzekwowania zobowiązań [Sobiecki 2016, s. 35].

Głównym celem opracowania jest analiza wpływu zarządzania wierzytelnościami na koszty w sprawozdaniu finansowym. Realizacja celu wymaga w szczególności:

- zidentyfikowania obszarów zarządzania wierzytelnościami,

- wskazania kierunków oddziaływania zarządzania wierzytelnościami na koszty prezentowane i nieprezentowane $\mathrm{w}$ sprawozdaniu finansowym,

- dokonania pomiaru kosztów zarządzania wierzytelnościami na podstawie danych prezentowanych w sprawozdaniach finansowych celowo dobranych (ze względu na przyjęty model zarządzania, porównywalność danych sprawozdawczych) jednostek należących do branży cechującej się wysokim poziomem należności na tle pozostałych,

- opracowania mierników oceny kosztochłonności zarządzania wierzytelnościami,

- zweryfikowania istnienia związku przyjętego modelu zarządzania wierzytelnościami z poziomem kosztów w badanych jednostkach poprzez porównanie przyjętych założeń i kosztochłonności zarządzania wierzytelnościami.

Dla realizacji procesu poznawczego dokonano przeglądu literatury przedmiotu i sprawozdań finansowych badanych jednostek za 2017 r. oraz wykorzystano metodę analizy i konstrukcji logicznej.

\section{Istota zarządzania wierzytelnościami}

Wnioskowanie o istocie zarządzania wierzytelnościami wobec różnorodności wpisanych w ten obszar tematyczny zagadnień wymaga dokonania zasadniczych uogólnień. Przede wszystkim zarządzanie wierzytelnościami stanowi integralny element zarządzania przedsiębiorstwem, co znajduje potwierdzenie w zakresie realizowanych funkcji zarządzania. Podstawową funkcją zarządzania jest planowanie, które

${ }^{1}$ Obliczenia własne na podstawie danych GUS [Główny Urząd Statystyczny 2018]. 
polega na wyznaczaniu celów i wyborze sposobu ich realizacji. Zarządzanie wierzytelnościami w obszarze planowania polega na rozpoznaniu możliwości wpływania na poziom, strukturę, przebieg obsługi wierzytelności, a następnie ustalaniu celów zgodnych z operacyjnymi i strategicznymi celami przedsiębiorstwa. Sprawna realizacja celów zarządzania wierzytelnościami wymaga w szczególności zapewnienia warunków technicznych, opracowania procedur pozyskiwania i komunikowania informacji, przydziału zadań i odpowiedzialności oraz budowy systemu oceny dokonań. Wskazane działania urzeczywistniają funkcję organizacyjną i motywacyjną w ramach zarządzania wierzytelnościami. Szczególne znaczenie dla skuteczności zarządzania wierzytelnościami, z uwagi na wrażliwość planów względem zmiany warunków rynkowych, ma funkcja kontrolna. Działania kontrolne powinny być realizowane na wszystkich etapach zarządzania wierzytelnościami i prowadzić do wykrycia odstępstw od przyjętych założeń i wprowadzenia działań korygujących.

Kolejną perspektywą analizy zarządzania wierzytelnościami jest podejście procesowe. Zarządzanie wierzytelnościami definiowane jest jako proces polegający na zapobieganiu powstawaniu przeterminowanych należności oraz ich odzyskiwaniu [Emerling 2013, s. 168]. W kontekście podejścia procesowego szczególnego znaczenia nabiera identyfikacja sekwencji czynności osadzonych w cyklu życia wierzytelności. W szczególności wyróżnić należy działania podejmowane na etapie²:

- negocjacji warunków kontraktu (np. ustalanie warunków kredytowania, weryfikacja zdolności kredytowej kontrahenta, ustalenie dodatkowych zabezpieczeń wierzytelności),

- zawierania kontraktu (np. stosowanie pieczęci prewencyjnej, ubezpieczenie wierzytelności, monitorowanie spłat obejmujące analizę stanów wierzytelności, informowanie o terminach płatności, uzyskiwanie dodatkowych zabezpieczeń w przypadku ujawnienia problemów finansowych dłużnika),

- wygaszania (rejestracja spłat, sprzedaż wierzytelności, realizacja zabezpieczeń, archiwizowanie dokumentacji),

- windykacji przedsądowej (np. wezwania do zapłaty, rejestracja kontaktów z dłużnikiem, negocjowanie warunków ugody),

- postępowania sądowego i egzekucyjnego (np. przygotowanie pism procesowych, składanie zeznań przed sądem).

Dokonany opis zarządzania wierzytelnościami z perspektywy realizowanych funkcji i zakresu zadaniowego stanowi punkt wyjścia do określenia istoty zarządzania wierzytelnościami, która przejawia się w systematycznym odziaływaniu na poziom, strukturę i obsługę wierzytelności w całym cyklu życia w celu ograniczenia ryzyka kredytowego, optymalizacji polityki kredytowej oraz zapewnienia płynności.

\footnotetext{
${ }^{2}$ Szczegółowy opis procesu zarządzania wierzytelnościami wraz ze stosowanymi narzędziami działania opisuje E. Nastarowicz [2012].
} 


\section{Kierunki oddziaływania zarządzania wierzytelnościami na poziom kosztów dzialalności gospodarczej}

W celu zidentyfikowania oddziaływania zarządzania wierzytelnościami na koszty podmiotu gospodarczego konieczne jest dwuaspektowe spojrzenie na zagadnienie. $\mathrm{Z}$ jednej strony koszty generowane są przez sprawowanie zarządzania wierzytelnościami. Poziom tej kategorii kosztów uzależniony jest od zakresu podejmowanych czynności, rodzaju stosowanych narzędzi oraz decyzji co do wykonywania czynności we własnym zakresie lub zlecania jednostkom zewnętrznym. Tego typu koszty wpływają na koszty działalności, lecz ich identyfikacja wyłącznie na podstawie sprawozdania finansowego nie jest możliwa. Z drugiej strony przyczyną powstawania kosztów jest niedostateczna skuteczność zarządzania wierzytelnościami w obszarze ograniczania ryzyka kredytowego, optymalizacji polityki kredytowej (polityki kredytowania odbiorców), zapewniania płynności. Tego rodzaju koszty stanowią przedmiot pogłębionej analizy, której głównym zadaniem było logiczne przyporządkowanie pozycji kosztów do zdiagnozowanych obszarów zarządzania wierzytelnościami na podstawie rozpoznanych związków przyczynowo-skutkowych.

Pierwszym z wyodrębnionych obszarów zarządzania wierzytelnościami jest ograniczanie ryzyka kredytowego. Jednostka w ramach zarządzania wierzytelnościami ma szereg możliwości zmniejszenia start z tytułu opóźnień w spłacie lub nieściągalności należności. Kluczową rolę odgrywają w tym obszarze takie narzędzia, jak wywiad gospodarczy (prowadzony we własnym zakresie lub zlecony jednostkom zewnętrznym), konstrukcja umowy (np. klauzula o dobrowolnym poddaniu się egzekucji, kary umowne), zabezpieczenie należności (np. hipoteka, zastaw, akredytywa, weksel), monitoring spłat. Podstawą oceny skuteczności zarządzania wierzytelnościami w tym obszarze może być udział należności przeterminowanych w ogóle należności, ustalony w następujący sposób:

$\begin{gathered}\text { Udział należności } \\ \text { przeterminowanych }\end{gathered}=\frac{\text { Stan końcowy przeterminowanych należności (brutto) }}{\text { Stan końcowy należności (brutto) }}$.

Wysokie wartości danego wskaźnika sygnalizują niedostateczną skuteczność sprawowania zarządzania wierzytelnościami, która znajduje odzwierciedlenie w poziomie kosztów ponoszonych w związku z finansowaniem przeterminowanych należności, utratą wartości należności oraz windykacją należności.

Koszty finansowania przeterminowanych należności oszacować można w następujący sposób:

Koszty finansowania przeterminowanych należności

$$
=\begin{gathered}
\text { Stan końcowy przeterminowanych } \\
\text { należności (brutto) }
\end{gathered}
$$

Stopa procentowa 
Stopa procentowa we wskazanej formule ustalana jest z uwzględnieniem średniej liczby dni zwłoki ważonej strukturą okresów przeterminowania należności oraz nominalnego rocznego oprocentowania kredytów krótkoterminowych. Sposób ustalenia stopy procentowej jest następujący:

$$
\underset{\text { procentowa }}{\text { Stopa }}=\frac{\text { Oprocentowanie } \times \quad \text { Liczba dni zwłoki }}{360 \mathrm{dni}} .
$$

W przypadku, gdy utrzymanie przeterminowanych należności wiąże się z koniecznością zaciągnięcia kredytów lub pożyczek, koszty finansowania przeterminowanych należności stanowią część kosztów finansowych z tytułu naliczonych odsetek. Formą rekompensaty poniesionych kosztów są przychody finansowe z tytułu odsetek naliczonych od przeterminowanych należności. W sytuacji, gdy utrzymanie przeterminowanych należności wiąże się z zamrożeniem własnych środków pieniężnych, generowane są koszty utraconych możliwości, które nie znajdują odzwierciedlenia w sprawozdaniu finansowym jednostki.

Kolejnym tytułem kosztów przypisanych do obszaru ograniczania ryzyka kredytowego jest utrata wartości należności. Koszty te stanowią sumę:

- wartości spisanych nieściągalnych należności, na które wcześniej nie utworzono odpisów aktualizujących,

- straty na sprzedaży należności,

- kwoty utworzonego odpisu aktualizującego wartość należności.

Koszty z tytułu utraty wartości należności prezentowane są odpowiednio w pozostałych kosztach operacyjnych w części dotyczącej należności głównej i w kosztach finansowych w części dotyczącej naliczonych odsetek za zwłokę w zapłacie oraz straty ze sprzedaży należności. W kosztach danego okresu wykazywana jest jedynie część kosztów z tytułu utraty wartości należności odpowiadająca kwocie utworzonego w danym okresie odpisu aktualizującego. W kosztach poprzednich okresów ujęta jest wartość należności umorzonych w danym okresie, która odpowiada kwocie wykorzystanych w danym okresie odpisów aktualizujących wartość należności. O łącznych kosztach utraty wartości dotyczących aktualnego stanu należności informuje saldo końcowe odpisów aktualizujących wartość należności. Straty z tytułu utraty wartości należności pomniejszają kwoty rozwiązanych odpisów aktualizujących wartość należności, z innych przyczyn niż wykorzystanie, oraz kwoty odzyskanej należności z tytułu realizacji zabezpieczeń.

Ostatnim tytułem kosztów przypisanych do obszaru ograniczania ryzyka kredytowego są prezentowane w pozostałych kosztach operacyjnych koszty windykacji należności, stanowiące sumę udokumentowanych, niezwróconych na podstawie ustawy o terminach zapłaty w transakcjach handlowych [Ustawa $\mathrm{z}$ dnia 8 marca 2013] kosztów windykacji przedsądowej i niezasądzonych kosztów postępowania sądowego [Ustawa z 28 lipca 2005], w szczególności:

- opłaty sądowe, 
- wydatki (np. zwroty kosztów podróży i noclegu oraz utraconych zarobków lub dochodów świadków, wynagrodzenia i zwroty kosztów poniesionych przez biegłych),

- koszty strony występującej osobiście lub przez pełnomocnika, który nie jest adwokatem, radcą prawnym lub rzecznikiem patentowym,

- koszty związane z reprezentowaniem strony przez adwokata, radcę prawnego lub rzecznika patentowego,

- inne koszty (np. koszty mediacji prowadzonej na skutek skierowania przez sąd). Kolejnym wyodrębnionym obszarem zarządzania wierzytelnościami jest optymalizacja polityki kredytowej, oznaczająca dążenie do zrównoważenia kosztów i korzyści związanych z należnościami [Brigham, Gapenski 2000, s. 247]. Źródłem korzyści jest wzrost przychodów ze sprzedaży osiągnięty za sprawą liberalizacji zasad oceny zdolności odbiorców do regulowania zobowiązań, wydłużania okresów kredytowania, ograniczenia zakresu wymaganych zabezpieczeń. Wzrost przychodów stymulowany zwiększeniem wolumenu kredytu kupieckiego wiąże się z kosztami wynikającymi z zamrożenia środków finansowych oraz wzrostem ryzyka kredytowego. Podstawą oceny założeń zarządzania wierzytelnościami w tym obszarze może być wskaźnik rotacji należności ustalony w następujący sposób:

$$
\begin{gathered}
\text { Wskaźnik rotacji } \\
\text { należności }
\end{gathered}=\frac{\text { Przeciętny poziom należności (netto) }}{\text { Roczne przechody ze sprzedaży }} .
$$

Wskaźnik rotacji należności informuje, ile razy w ciągu roku przedsiębiorstwo odtwarza przeciętny stan należności. W literaturze przyjęto, iż wartość tego wskaźnika powinna zawierać się w przedziale od 7 do 10 [Dębski (red.) 2005, s. 88]. Wartości wskaźnika ze wskazanego przedziału oznaczają, że polityka kredytowa kształtowana jest $\mathrm{z}$ uwzględnieniem skutków dla wolumenu sprzedaży i strat w tytułu niewypłacalności kontrahentów. Podejście takie określane jest w literaturze jako umiarkowane. Inne wskazywane w literaturze podejście to podejście konserwatywne, oznaczające rygorystyczne kształtowanie warunków udzielania kredytu kupieckiego. $\mathrm{W}$ tym przypadku wskaźnik rotacji osiąga wartości wyższe niż 10 . Z kolei niższe niż 7 wartości wskaźnika rotacji oznaczają luźne kształtowanie warunków udzielania kredytu kupieckiego. Takie podejście określane jest jako liberalne.

Zmiana w formule obliczeniowej wskaźnika rotacji należności, polegająca na zastąpieniu rocznych dziennymi przychodami ze sprzedaży, umożliwia dokonanie oceny zarządzania wierzytelnościami na podstawie cyklu należności w dniach, który informuje o średniej liczbie dni oczekiwania na uregulowanie należności od momentu zawarcia kontraktu. Im wyższa wartość wskaźnika, tym bardziej liberalne podejście do polityki kredytowej.

Podejście do polityki kredytowej znajduje odzwierciedlenie w poziomie kosztów ponoszonych $\mathrm{w}$ związku $\mathrm{z}$ finansowaniem nieprzeterminowanych należności, które oszacować można w następujący sposób: 


$\begin{gathered}\text { Koszty finansowania } \\ \text { nieprzeterminowanych } \\ \text { należności }\end{gathered}=\begin{gathered}\text { Stan końcowy } \\ \text { nieprzeterminowanych } \\ \text { należności }\end{gathered} \times \begin{gathered}\text { Stopa } \\ \text { procentowa }\end{gathered}$.

Stopa procentowa we wskazanej formule ustalana jest z uwzględnieniem średniej liczby dni spłaty równej długości cyklu należności oraz nominalnego rocznego oprocentowania kredytów krótkoterminowych. Sposób ustalenia stopy procentowej jest następujący:

$$
\underset{\text { Stopa }}{\text { procentowa }}=\frac{\text { Oprocentowanie } \times \text { Liczba dni spłaty }}{360 \mathrm{dni}} .
$$

W przypadku, gdy utrzymanie należności wiąże się z koniecznością zaciągnięcia kredytów, pożyczek lub opóźnieniami w regulowaniu zobowiązań, koszty finansowania należności stanowią część kosztów finansowych z tytułu naliczonych odsetek. W sytuacji, gdy z należnościami wiąże się z zamrożenie własnych środków pieniężnych lub udzielanie upustów, generowane są koszty utraconych możliwości, które nie znajdują odzwierciedlenia w sprawozdaniu finansowym.

Kolejnym wyodrębnionym obszarem zarządzania wierzytelnościami jest zapewnianie płynności w znaczeniu zdolności do terminowego regulowania zobowiązań. Podstawowe zadania zarządzania wierzytelnościami w tym obszarze to planowanie źródeł finansowania należności. Zatem na potrzeby oceny celowy jest pomiar wskaźnika pokrycia zobowiązań należnościami według następującej formuły:

$$
\underset{\text { zobowiązań należnościami }}{\text { Wskaźnik pokrycia }}=\frac{\text { Przeciętny poziom należności (netto) }}{\text { Przeciętny poziom zobowiązań (netto) }} \text {. }
$$

Za graniczną wartość wskaźnika pokrycia zobowiązań należnościami przyjmuje się w literaturze wartość jeden [Gołaszewski i in. 2001, s. 45]. Problemy wynikające z krótkoterminowych zakłóceń płynności generują koszty z tytułu naliczonych odsetek od przeterminowanych zobowiązań, kar naliczonych w związku z niedotrzymaniem warunków umów, kosztów realizacji zabezpieczeń zobowiązań. Tego typu koszty znajdują odzwierciedlenie w pozostałych kosztach operacyjnych lub kosztach finansowych. Koszty wykazywane w sprawozdaniu finansowym nie uwzględniają natomiast strat $\mathrm{z}$ tytułu utraconych przychodów $\mathrm{w}$ związku z zerwaniem na skutek problemów z wypłacalnością kontraktów. Długoterminowe problemy z płynnością mogą doprowadzić do sytuacji, gdy zobowiązania przewyższają wartość majątku przedsiębiorstwa, co skutkuje ogłoszeniem upadłości. W sprawozdaniu finansowym jednostek w upadłości wykazywane są bez szczegółowego wyodrębnienia koszty takie, jak:

- koszty opłat sądowych, obwieszczeń, ogłoszeń oraz samego postępowania dowodowego,

- wynagrodzenie powołanych przez sąd: syndyka, nadzorcy sądowego, zarządcy, ich zastępców oraz innych osób, jeśli wydatki te są uzasadnione, 
- wynagrodzenie i wydatki członków rady wierzycieli,

- wynagrodzenie osób zatrudnionych przez kierownika jednostki na czas postępowania za zgodą sędziego,

- wynagrodzenia dla dotychczasowych pracowników za okres trwania postępowania,

- składki na ubezpieczenia społeczne związane z wymienionymi wynagrodzeniami,

- odprawy i odszkodowania dla zwalnianych pracowników,

- koszty prowadzenia działalności jednostki w czasie trwania procedur upadłościowych, w tym w szczególności podatki i daniny publiczne oraz wydatki związane z zarządem masy upadłości (na podst.: [Kuzior 2010, s. 128]).

Podsumowując rozważania na temat kosztów wynikających z niedostatecznej skuteczności zarządzania wierzytelnościami w poszczególnych obszarach, należy zaznaczyć, iż na poziom tego rodzaju kosztów mają wpływ, poza przyjętymi metodami szacowania, także rachunkowe metody ujmowania i wyceny uwzględnianych w formułach obliczeniowych kategorii. Sygnalizowany problem jest szczególnie istotny w kontekście wprowadzonego regulacjami MSSF 9 modelu oczekiwanych strat kredytowych.

\section{Ocena związku pomiędzy przyjętymi założeniami i kosztochłonnością zarządzania wierzytelnościami}

Dla oceny wpływu zarządzania wierzytelnościami na koszty w sprawozdaniu finansowym zasadnicze znaczenie ma wybór jednostek do badań. Przede wszystkim jednostki te powinny reprezentować branżę cechującą się wysokim poziomem należności na tle pozostałych. Analiza aktualnych danych statystycznych [Główny Urząd Statystyczny 2018] ujawniła, iż najwyższy poziom należności wykazuje przetwórstwo przemysłowe. Łączna kwota należności z działalności zaklasyfikowanej do sekcji C według PKD [Rozporządzenie Rady Ministrów z 24 grudnia 2007] wynosi 198 853,6 mln zł i stanowi 39,5 \%³ ogólnej wartości należności w gospodarce krajowej na koniec 2017 r. W wyłonionym sektorze najwyższy poziom należności (29 $794 \mathrm{mln}$ zł) przynależy produkcji artykułów spożywczych. Spośród spółek, których akcje notowane są na Giełdzie Papierów Wartościowych w Warszawie, na potrzeby przeprowadzenia badań wybrano trzy spółki cechujące się wysokim poziomem należności i różniące się znacznie pod względem obrotowości należności. Są to ZT „Kruszwica” S.A., Indykpol S.A., Wawel S.A. Na podstawie danych prezentowanych w sprawozdaniach finansowych za 2017 r., sporządzanych we wszystkich wybranych spółkach zgodnie z Międzynarodowymi Standardami Sprawozdawczości Finansowej, opracowano charakterystyki badanych spółek zgodnie z zasadami przedstawionymi we wcześniejszym fragmencie opracowania. Stosowne obliczenia wykonano z wykorzystaniem danych o wartości: stanów końcowych i przeciętnych

${ }^{3}$ Obliczenia własne na podstawie danych GUS [Główny Urząd Statystyczny 2018]. 
należności z tytułu dostaw i usług z działalności kontynuowanej (z wyszczególnieniem przeterminowanych, nieprzeterminowanych, w kwocie brutto, netto), odpisów aktualizujących wartość należności z tytułu dostaw i usług (z wyszczególnieniem salda początkowego, salda końcowego, kwoty utworzonego, rozwiązanego i wykorzystanego w danym roku odpisu), stanu przeciętnego zobowiązań z tytułu dostaw i usług, rocznych przychodów ze sprzedaży i łącznych rocznych kosztów działalności, naliczonych odsetek od zobowiązań. Na potrzeby obliczeń przyjęto maksymalną stopę oprocentowania kredytów, czyli 10\% (czterokrotność aktualnej stopy lombardowej).

W tabeli 1 zaprezentowano wyniki oceny zarządzania wierzytelnościami pod kątem przyjętych założeń i poziomu generowanych kosztów w ZT „Kruszwica” S.A. W świetle uzyskanych wyników można wnioskować, iż priorytetowe znaczenie w zarządzaniu wierzytelnościami w ZT „Kruszwica” S.A. ma zapewnienie bezpieczeństwa finansowego. Przedsiębiorstwo prowadzi restrykcyjną politykę kredytowania odbiorców, o czym świadczy krótki cykl należności (14 dni) w porównaniu ze średnim w sektorze $(35 \mathrm{dni})^{4}$ oraz wysoki poziom wskaźnika rotacji należności $(26,17)$, przewyższający ponad dwukrotnie maksymalną zalecaną wartość. Najwyższy poziom kosztów zarządzania wierzytelnościami generuje obszar ograniczania

Tabela 1. Wyniki pomiaru kosztów i oceny zarządzania wierzytelnościami w ZT „Kruszwica” S.A.

\begin{tabular}{|c|c|c|c|c|}
\hline Cele & $\begin{array}{l}\text { Mierniki } \\
\text { oceny }\end{array}$ & $\begin{array}{l}\text { Wartość } \\
\text { miernika }\end{array}$ & Tytuły kosztów & $\begin{array}{l}\text { Koszty } \\
\text { w tys. zł }\end{array}$ \\
\hline \multirow{4}{*}{$\begin{array}{l}\text { Ograniczenie } \\
\text { ryzyka } \\
\text { kredytowego }\end{array}$} & \multirow{4}{*}{$\begin{array}{l}\text { Odsetek } \\
\text { należności } \\
\text { przeterminowanych }\end{array}$} & \multirow{4}{*}{0,39} & $\begin{array}{l}\text { Koszty finansowania } \\
\text { przeterminowanych należności }\end{array}$ & 721 \\
\hline & & & $\begin{array}{l}\text { Koszty z tytułu utraty wartości } \\
\text { należności }\end{array}$ & 196 \\
\hline & & & Koszty windykacji & $\begin{array}{c}\text { brak } \\
\text { danych }\end{array}$ \\
\hline & & & $\Sigma$ kosztów danego obszaru & 917 \\
\hline \multirow{2}{*}{$\begin{array}{l}\text { Optymalizacja } \\
\text { polityki } \\
\text { kredytowej }\end{array}$} & $\begin{array}{l}\text { Długość cyklu } \\
\text { należności }\end{array}$ & $14 \mathrm{dni}$ & $\begin{array}{l}\text { Koszty finansowania należności } \\
\text { nieprzeterminowanych }\end{array}$ & 239 \\
\hline & $\begin{array}{l}\text { Wskaźnik rotacji } \\
\text { należności }\end{array}$ & 26,17 & $\Sigma$ kosztów danego obszaru & 239 \\
\hline \multirow{2}{*}{$\begin{array}{l}\text { Zapewnianie } \\
\text { płynności }\end{array}$} & \multirow{2}{*}{$\begin{array}{l}\text { Wskaźnik pokrycia } \\
\text { zobowiązań } \\
\text { należnościami }\end{array}$} & \multirow[t]{2}{*}{0,39} & $\begin{array}{l}\text { Koszty z tytułu nieterminowego } \\
\text { regulowania zobowiązań }\end{array}$ & 29 \\
\hline & & & $\sum$ kosztów danego obszaru & 29 \\
\hline & & & $\begin{array}{l}\Sigma \text { kosztów zarządzania } \\
\text { wierzytelnościami }\end{array}$ & 1185 \\
\hline
\end{tabular}

Źródło: opracowanie własne na postawie Jednostkowego sprawozdania finansowego ZT „Kruszwica” S.A. za 2017 r.

${ }^{4}$ Wartość zaokrąglona do pełnych dni [Dudycz, Skoczylas 2018, s. 69]. 
ryzyka kredytowego. Przedsiębiorstwo niweluje negatywne skutki występowania przeterminowanych należności, ubezpieczając swoje wierzytelności. Zgodnie z wyjaśnieniami zawartymi w notach do sprawozdania finansowego ubezpieczeniu podlega prawie cała wartość udzielonego kredytu kupieckiego, z wyjątkiem sytuacji gdy na pokrycie wierzytelności przewidziane jest zabezpieczenie majątkowe. W przypadku, gdy ubezpieczyciel odmówi ubezpieczenia wierzytelności od określonego kontrahenta, wówczas wymagane jest dokonanie przedpłaty. Ważnym instrumentem wykorzystywanym w zarządzaniu wierzytelnościami jest faktoring. Łączna wartość należności sprzedanych (nieujętych w wartości należności wykazywanych w sprawozdaniu z sytuacji finansowej) wyniosła w 2017 r. 163480 tys. zł. Jednostka deklaruje, iż należności są na bieżąco monitorowane, a realizacja zamówień od klienta odbywa się tylko w ramach przyznanych limitów kredytowych oraz pod warunkiem braku należności przeterminowanych. Naliczanie odsetek od należności przeterminowanych uzależnione jest od osądu słuszności naliczania wobec konkretnych kontrahentów, dokonywanego z uwzględnieniem dotychczasowej współpracy, liczby dni zwłoki, przyczyn mogących powodować opóźnienia w płatnościach oraz planów dotyczących dalszych kontaktów.

Kolejnym badanym przedsiębiorstwem jest Indykpol S.A. Wyniki oceny zarządzania wierzytelnościami $\mathrm{w}$ tym przedsiębiorstwie pod kątem przyjętych założeń i poziomu generowanych w poszczególnych obszarach kosztów prezentuje tabela 2. Wyniki obliczeń w świetle postulowanych w literaturze poziomów wskaźni-

Tabela 2. Wyniki pomiaru kosztów i oceny zarządzania wierzytelnościami w Indykpol S.A.

\begin{tabular}{|c|c|c|c|c|}
\hline Cele & $\begin{array}{l}\text { Mierniki } \\
\text { oceny }\end{array}$ & $\begin{array}{l}\text { Wartość } \\
\text { miernika }\end{array}$ & Tytuły kosztów & $\begin{array}{c}\text { Koszty } \\
\text { w tys. zł }\end{array}$ \\
\hline \multirow{4}{*}{$\begin{array}{l}\text { Ograniczenie } \\
\text { ryzyka } \\
\text { kredytowego }\end{array}$} & \multirow{4}{*}{$\begin{array}{l}\text { Odsetek } \\
\text { należności } \\
\text { przeterminowanych }\end{array}$} & \multirow{4}{*}{0,23} & $\begin{array}{l}\text { Koszty finansowania } \\
\text { przeterminowanych należności }\end{array}$ & 388 \\
\hline & & & $\begin{array}{l}\text { Koszty z tytułu utraty wartości } \\
\text { należności }\end{array}$ & 108 \\
\hline & & & Koszty windykacji & brak danych \\
\hline & & & $\Sigma$ kosztów danego obszaru & 496 \\
\hline \multirow{2}{*}{$\begin{array}{l}\text { Optymalizacja } \\
\text { polityki } \\
\text { kredytowej }\end{array}$} & $\begin{array}{l}\text { Długość cyklu } \\
\text { należności }\end{array}$ & $53 \mathrm{dni}$ & $\begin{array}{l}\text { Koszty finansowania należności } \\
\text { nieprzeterminowanych }\end{array}$ & 1409 \\
\hline & $\begin{array}{l}\text { Wskaźnik rotacji } \\
\text { należności }\end{array}$ & 6,83 & $\Sigma$ kosztów danego obszaru & 1409 \\
\hline \multirow{2}{*}{$\begin{array}{l}\text { Zapewnianie } \\
\text { płynności }\end{array}$} & \multirow{2}{*}{$\begin{array}{l}\text { Wskaźnik pokrycia } \\
\text { zobowiązań } \\
\text { należnościami }\end{array}$} & \multirow[t]{2}{*}{0,82} & $\begin{array}{l}\text { Koszty z tytułu nieterminowego } \\
\text { regulowania zobowiązań }\end{array}$ & 22 \\
\hline & & & $\Sigma$ kosztów danego obszaru & 22 \\
\hline & & & $\begin{array}{l}\Sigma \text { kosztów zarządzania } \\
\text { wierzytelnościami }\end{array}$ & 1927 \\
\hline
\end{tabular}

Źródło: opracowanie własne na postawie Sprawozdania finansowego Indykpol S.A. za 2017 r. 
ków ujawniają umiarkowaną politykę kredytową w badanym przedsiębiorstwie. Wskaźnik rotacji należności jest bliski granicznej wartości 7, zaś wskaźnik pokrycia zobowiązań należnościami jest bliski jedności. Najwyższy poziom kosztów zarządzania wierzytelnościami wynika z finansowania należności nieprzeterminowanych, co wskazuje na wykorzystywanie kredytu kupieckiego dla zwiększenia wolumenu sprzedaży. Przed zwiększonym ryzykiem związanym z rozluźnieniem warunków udzielania kredytów przedsiębiorstwo zabezpiecza się, ubezpieczając swoje wierzytelności. Spółka ma zawartą umowę z ubezpieczycielem, zgodnie z którą należności handlowe są ubezpieczone średnio w 90\% wartości do wysokości przyznanego limitu. Jeżeli limit nie może zostać przyznany lub zostanie klientowi cofnięty, w sytuacji zagrożenia utraty wierzytelności spółka tworzy odpis na utratę wartości.

Kolejnym badanym przedsiębiorstwem jest Wawel S.A. Wyniki oceny zarządzania wierzytelnościami w tym przedsiębiorstwie pod kątem przyjętych założeń i poziomu generowanych w poszczególnych obszarach kosztów prezentuje tabela 3. Zaprezentowane w tabeli wyniki obliczeń ujawniają około trzykrotnie dłuższy niż branżowy cykl należności oraz znacznie niższy niż rekomendowany wskaźnik rotacji należności. Na tej podstawie uprawnione jest wnioskowanie o liberalnej polityce kredytowej. Znajduje to odzwierciedlenie w istotnym poziomie kosztów przypisanych do danego obszaru zarządzania wierzytelnościami. Zgodnie z wyjaśnieniamizawartymi w notach do sprawozdania finansowego spółka zawiera transakcje wyłącznie z renomowanymi firmami o dobrej zdolności kredytowej. Wszyscy klienci,

Tabela 3. Wyniki pomiaru kosztów i oceny zarządzania wierzytelnościami w Wawel S.A.

\begin{tabular}{|c|c|c|c|c|}
\hline Cele & $\begin{array}{l}\text { Mierniki } \\
\text { oceny }\end{array}$ & $\begin{array}{l}\text { Wartość } \\
\text { miernika }\end{array}$ & Tytuły kosztów & $\begin{array}{c}\text { Koszty } \\
\text { w tys. zł }\end{array}$ \\
\hline \multirow{4}{*}{$\begin{array}{l}\text { Ograniczenie } \\
\text { ryzyka } \\
\text { kredytowego }\end{array}$} & \multirow{4}{*}{$\begin{array}{l}\text { Odsetek } \\
\text { należności } \\
\text { przeterminowanych }\end{array}$} & \multirow{4}{*}{0,09} & $\begin{array}{l}\text { Koszty finansowania } \\
\text { przeterminowanych należności }\end{array}$ & 170 \\
\hline & & & $\begin{array}{l}\text { Koszty z tytułu utraty wartości } \\
\text { należności }\end{array}$ & 1652 \\
\hline & & & Koszty windykacji & $\begin{array}{r}\text { brak } \\
\text { danych }\end{array}$ \\
\hline & & & $\Sigma$ kosztów danego obszaru & 1822 \\
\hline \multirow{2}{*}{$\begin{array}{l}\text { Optymalizacja } \\
\text { polityki } \\
\text { kredytowej }\end{array}$} & $\begin{array}{l}\text { Długość cyklu } \\
\text { należności }\end{array}$ & $110 \mathrm{dni}$ & $\begin{array}{l}\text { Koszty finansowania należności } \\
\text { nieprzeterminowanych }\end{array}$ & 5320 \\
\hline & $\begin{array}{l}\text { Wskaźnik rotacji } \\
\text { należności }\end{array}$ & 3,27 & $\Sigma$ kosztów danego obszaru & 5320 \\
\hline \multirow{2}{*}{$\begin{array}{l}\text { Zapewnianie } \\
\text { płynności }\end{array}$} & \multirow{2}{*}{$\begin{array}{l}\text { Wskaźnik pokrycia } \\
\text { zobowiązań } \\
\text { należnościami }\end{array}$} & \multirow[t]{2}{*}{3,05} & $\begin{array}{l}\text { Koszty z tytułu nieterminowego } \\
\text { regulowania zobowiązań }\end{array}$ & 15 \\
\hline & & & $\Sigma$ kosztów danego obszaru & 15 \\
\hline & & & $\begin{array}{l}\Sigma \text { kosztów zarządzania } \\
\text { wierzytelnościami }\end{array}$ & 7157 \\
\hline
\end{tabular}

Źródło: opracowanie własne na postawie Sprawozdania finansowego Wawel S.A. za 2017 r. 
którzy pragną korzystać z kredytów kupieckich, poddawani są procedurom wstępnej weryfikacji. Ponadto prowadzony jest bieżący monitoring stanów należności. Skuteczność opisanych działań odzwierciedla niski udział przeterminowanych należności. W tym kontekście powstaje wątpliwość co do zasadności poziomu kosztów z tytułu utraty wartości należności. Jednym z możliwych wyjaśnień jest wykorzystywanie odpisów aktualizujących należności jako instrumentu polityki rachunkowości. Prowadzone w tym zakresie badania w innych jednostkach wykazały, iż znaczna wartość dokonywanych odpisów aktualizujących należności z roku poprzedniego była w tych jednostkach odwracana (rozwiązywana w związku z ich niewykorzystaniem), co złagodziło skutki wynikowe (oraz bilansowe) odpisów bieżących i w efekcie wygładzało wynik finansowy [Kumor, Poniatowska 2014, s. 131]. Dodatkowym wskazywanym w notach do sprawozdania sposobem ograniczania strat z tytułu nieściągalnych należności są ubezpieczenia.

Przeprowadzona ocena badanych jednostek potwierdziła, iż jednostki te różnią się pod względem przyjętych zasad i skuteczności zarządzania wierzytelnościami w obszarze ograniczenia ryzyka kredytowego, optymalizacji polityki kredytowej i zabezpieczenia przed utratą płynności. Najbardziej różniącym dane spółki elementem jest podejście do polityki kredytowej, z tego względu stanowi ono kryterium kategoryzacji jednostek na potrzeby dalszych analiz. Zgodnie z przyjętymi w literaturze przedmiotu wartościami granicznymi ZT „Kruszwica” S.A. reprezentuje podejście konserwatywne (wartość wskaźnika rotacji należności znacznie powyżej 10), Indykpol S.A. reprezentuje podejście umiarkowane (wartość wskaźnika rotacji należności bliska przedziału od 7 do 10), Wawel S.A. reprezentuje podejście liberalne (wartość wskaźnika rotacji należności znacznie niższa niż 7).

Dla oceny wpływu zarządzania wierzytelnościami na koszty w sprawozdaniu finansowym wymagane jest porównanie badanych jednostek pod kątem ponoszonych kosztów zarządzania wierzytelnościami. Na potrzeby tak ukierunkowanej analizy opracowano zestaw mierników kosztochłonności, których wartości dla poszczególnych spółek prezentuje tabela 4.

Tabela 4. Kosztochłonność zarządzania wierzytelnościami w badanych jednostkach w $2017 \mathrm{r}$.

\begin{tabular}{|c|c|c|c|}
\hline Mierniki oceny kosztochłonności & $\begin{array}{c}\text { ZT „Kruszwica” } \\
\text { S.A. }\end{array}$ & Indykpol S.A. & Wawel S.A. \\
\hline Koszty zarządzania wierzytelnościami (zł) & \multirow{2}{*}{0,47} & \multirow{2}{*}{2,16} & \multirow{2}{*}{14,03} \\
\hline Koszty ogółem (tys. zł) & & & \\
\hline Koszty zarządzania wierzytelnościami (zł) & \multirow{2}{*}{0,46} & \multirow{2}{*}{2,20} & \multirow{2}{*}{11,57} \\
\hline Przychody ze sprzedaży (tys. zł) & & & \\
\hline Koszty zarządzania wierzytelnościami & \multirow{2}{*}{12,53} & \multirow{2}{*}{16,06} & \multirow{2}{*}{38,29} \\
\hline Należności z tyt. dostaw i usług (tys. zł) & & & \\
\hline
\end{tabular}

Źródło: opracowanie własne na podstawie sprawozdań finansowych badanych podmiotów za 2017 r. 
W świetle ujawnionych danych znaczenie kosztów zarządzania wierzytelnościami jest różne w różnych podejściach. Największe znaczenie mają w podejściu liberalnym stosowanym w Wawel S.A., co potwierdza najwyższy udział kosztów zarządzania wierzytelnościami w kosztach ogółem $(14,03)$, najwyższa kwota przychodów przeznaczanych na pokrycie kosztów zarządzania wierzytelnościami $(11,57 \mathrm{zł}$ z 1000 zł przychodów) oraz najwyższa kwota kosztów generowana przez 1 tys. zł zaangażowany w należności (38,29 zł). Najniższe znaczenie kosztów zarządzania wierzytelnościami występuje w podejściu restrykcyjnym stosowanym w ZT „Kruszwica” S.A., co potwierdza najniższy udział kosztów zarządzania wierzytelnościami w kosztach ogółem $(0,47)$, najniższa kwota przeznaczanych przychodów na pokrycie kosztów zarządzania $(0,46$ zł z 1000 zł przychodów) oraz najniższa kwota kosztów generowana przez 1 tys. zł zaangażowany w należności (12,53 zł). Przedsiębiorstwo Indykpol S.A., stosujące podejście umiarkowane, uzyskało wartości mieszczące się w przedziale wyznaczonym przez reprezentanta podejścia konserwatywnego i liberalnego.

\section{Zakończenie}

Przeprowadzone badania ujawniły istnienie związku pomiędzy przyjętymi w badanych jednostkach założeniami i kosztochłonnością zarządzania wierzytelnościami. Dokonana egzemplifikacja wpływu zarządzania wierzytelnościami na koszty w sprawozdaniu finansowym rzutuje na rozumienie pojęcia ,zarządzanie wierzytelnościami”. Powiązanie modelu zarządzania wierzytelnościami z poziomem kosztów oraz identyfikacja zakresu zarządzania wierzytelnościami szerszego niż obszar polityki kredytowej pozwalają zdefiniować zarządzanie wierzytelnościami jako podsystem systemu zarządzania przedsiębiorstwem, który oddziałuje na poziom, strukturę i proces obsługi wierzytelności w całym cyklu życia w celu ograniczenia bieżących i przyszłych strat z tytułu ryzyka kredytowego, niewłaściwej polityki kredytowania odbiorców oraz utraty płynności.

\section{Literatura}

Brigham E.F., Gapenski L.C., 2000, Zarządzanie finansami, PWE, Warszawa.

Dębski W. (red.), 2005, Teoretyczne i praktyczne aspekty zarządzania finansami przedsiębiorstwa, Wydawnictwo Naukowe PWN, Warszawa.

Dudycz T., Skoczylas W., 2018, Wskaźniki finansowe przedsiębiorstw wedtug dziatów (sektorów) za $2016 r$., Rachunkowość, $\mathrm{nr} 4$.

Emerling I., 2013, Wycena i ewidencja środków pieniężnych i rozrachunków, Wydawnictwo Marina, Wrocław.

Gołaszewski P., Urbanek P., Walińska E., 2001, Analiza sprawozdań finansowych, Fundacja Rozwoju Rachunkowości w Polsce, Łódź.

Główny Urząd Statystyczny, 2018, Wyniki finansowe podmiotów gospodarczych I-XII 2017 r., Warszawa, ww.stat.gov.pl (14.05.2018). 
Jednostkowe sprawozdania finansowe spółek Indykpol S.A., Wawel S.A., ZT „Kruszwica” S.A. za $2017 \mathrm{r}$.

Kumor I., Poniatowska L., 2014, Odpisy aktualizujące należności jako instrument polityki rachunkowości ksztattujący wynik finansowy na przykładzie spótek z branży energetycznej objętych WIG 30, Prace Naukowe Uniwersytetu Ekonomicznego we Wrocławiu, nr 373.

Kuzior A., 2010, Zasady wyceny bilansowej i ich wptyw na ksztalt sprawozdań finansowych. Dylematy metodyczne, Wyższa Szkoła Biznesu, Dąbrowa Górnicza.

Nastarowicz E., 2012, Zmiana modelu zarządzania wierzytelnościami w przedsiębiorstwach działajacych $w$ Polsce, Zeszyty Naukowe Uniwersytetu Szczecińskiego, nr 689, Finanse, Rynki Finansowe, Ubezpieczenia, nr 50, s. 339-350.

Rozporządzenie Rady Ministrów z dnia 24 grudnia 2007 r. w sprawie Polskiej Klasyfikacji Działalności (PKD), Dz.U. z 2007, nr 251, poz.1885.

Sobiecki R., 2016, Koszty transakcyjne w kontekście ochrony praw wierzycieli, Biuletyn PTE, nr 4(75).

Ustawa z dnia 8 marca 2013 r. o terminach zapłaty w transakcjach handlowych, Dz.U. z 2016 r., poz. 684 .

Ustawa z dnia 28 lipca 2005 r. o kosztach sądowych w sprawach cywilnych, Dz.U z 2016 r., poz. 623. 